\title{
EDUKASI MANFAAT VAKSINASI COVID-19 DAN MENANGKAL HOAX
}

\author{
Martina Pakpahan ${ }^{1 *}$, Deborah Siregar ${ }^{2}$, Lina Berliana Togatorop ${ }^{3}$, Marisa \\ Junianti Manik ${ }^{4}$, Masrida Adolina Panjaitan ${ }^{5}$, Novita Susilawati Barus ${ }^{6}$ \\ 1-6 Fakultas Keperawatan Universitas Pelita Harapan \\ Email Korespondensi: martina.pakpahan@uph.edu
}

Disubmit: 21 Oktober $2021 \quad$ Diterima: 11 Desember $2021 \quad$ Diterbitkan: 02 Januari 2022 DOI: https://doi.org/10.33024/jkpm.v1i1.5354

\begin{abstract}
ABSTRAK
Vaksianasi Covid-19 menjadi program nasional yang dicanangkan Pemerintah bagi seluruh rakyat Indonesa di ke 34 Provinsi, dimulai sejak 13 Januari 2021 dan ditargetkan rampung pada Desember 2021. Kegiatan Pengabdian kepada masyarakat (PkM) dilakukan pada tanggal 4 Juni 2021 dalam bentuk webinar kesehatan diselenggarakan oleh Fakultas Keperawatan UPH bekerjasama dengan Dinas Kesehatan Kabupaten Tangerang, Dinas Kesehatan Provinsi Bali. Tujuan kegiatan ini untuk mendukung pemerintah dalam capaian vaksinasi Covid-19 melalui peningkatan pengetahuan dan sikap positif masyarakat untuk mengikuti vaksinasi. Kegiatan ditujukan bagi masyarakat umum dan diikuti oleh 227 peserta. Hasil kegiatan menunjukkan hal-hal sebagai berikut: 1) Karakteristik Peserta: berasal dari berbagai Provinsi (mayoritas dari Banten yaitu sebanyak 22\%), beragam profesi (mayoritas adalah mahasiswa sebanyak $62,6 \%$ ), beragam jenjang pendidikan (mayoritas adalah S1 yaitu sebanyak 67,4\%) dan berbagai usia (mayoritas adalah 17-25 tahun yaitu sebanyak 66,5\%); 2) Gambaran pengetahuan peserta terkait vaksin COVID-19 sudah baik. Hal ini terlihat dari rerata nilai pre-test sebesar 7.28 dan Nilai Median 7 yang kemudian meningkat pada post-test dengan rerata nilai 8.29 dan Nilai Median 9; 3) Sebanyak $207(91,2 \%)$ peserta belum pernah terinfeksi COVID-19, sebanyak 220 (96,9\%) peserta memiliki sikap positif (menilai penting) pemberian vaksin COVID-19, sebanyak $106(46,7 \%)$ peserta mendapatkan informasi terkait vaksin COVID-19 dari media sosial, dan sebanyak 122 (53,7\%) peserta belum pernah mendapatkan vaksin COVID-19; 4) Peserta antusias mengikuti webinar dari awal sampai akhir dan menilai kegiatan baik (memuaskan). Saran untuk lembaga mitra, agar dapat memanfaatkan media sosial secara maksimal untuk sosialisasi dan edukasi terkait vaksinasi COVID-19.
\end{abstract}

Kata Kunci: COVID-19, Imunitas, Masyarakat, Pemerintah, Vaksin

\section{ABSTRACT}

The Covid-19 vaccination is a national program launched by the government for all Indonesians in 34 provinces beginning January 13, 2021 and expected to be completed in December 2021. A Community Service Activity (PkM) was held on June 4, 2021 in the form of a health webinar organized by The UPH Faculty of Nursing in collaboration with the Tangerang District Health Office and the Bali Provincial Health Office. The purpose of this activity is to support the government in achieving Covid-19 vaccination by increasing public awareness 
and positive attitudes toward vaccination. The activity was intended for the general public and had 227 participants. The results of the activity showed the following: 1) Characteristics of Participants: came from various provinces (the majority were from Banten, which was $22 \%$ ), various professions (the majority were students, as many as 62.6\%), various levels of education (the majority were Bachelors, namely 67.4\%) and various ages (the majority are 17-25 years, which is 66.5\%); 2) The description of participants' knowledge regarding the COVID-19 vaccine is good. This can be seen from the average pre-test score of 7.28 and a median value of 7 which then increased in the post-test with an average value of 8.29 and a median value of 9; 3) A total of 207 (91.2\%) participants had never been infected with COVID-19, as many as 220 (96.9\%) participants had a positive attitude (judged it was important) to administer the COVID-19 vaccine, as many as 106 (46.7\%) participants received information related to the COVID-19 vaccine from social media, and as many as 122 (53.7\%) participants had never received the COVID-19 vaccine; 4) Participants participated enthusiastically in the webinar from start to finish and rated the activity as good (satisfactory). Suggestions for partner institutions to make the best use of social media for COVID-19 vaccination socialization and education.

Keywords: COVID-19, Immunity, Society, Government, Vaccines

\section{PENDAHULUAN}

Awal tahun 2020, Indonesia dikejutkan dengan adanya virus baru yaitu Corona virus disease (COVID-19) yang merupakan penyakit menular yang disebabkan oleh novel Coronavirus pertama kali terindentifikasi pada Desember 2019 di Wuhan, Cina. Covid-19 kemudian diumumkan sebagai pandemi oleh World Health Organization (WHO) pada bulan Maret 2020 (World Health Organization., 2021). Pada bulan April 2020 pemerintah Indonesia memberlakukan Pembatasan Sosial Berskala Besar (PSBB) untuk meminimalkan penyebaran COVID-19, namun kkemudian kebijakan ini berdampak terhadap penurunan pertumbuhan ekonomi nasional karena hampir 55\% penduduk Indonesia berdomisili di Pulau Jawa (Satuan Tugas Penanganan COVID-19, 2020). Oleh karena itu, pada bulan Juni 2020, pemerintah Indonesia mulai memberlakukan kegiatan new normal yaitu masyarakat diperbolehkan melakukan kegiatan diluar rumah dengan menerapkan protocol kesehatan untuk tetap menjaga penyebaran COVID-19 serta membantu pengembangan ekonomi masyarakat (Satuan Tugas Penanganan COVID-19, 2020).

Satuan Tugas Penanganan COVID-19 juga gencar menginformasikan aturan perilaku hidup di era new normal dengan tetap menjaga dan mematuhi adanya Iman, Aman, dan Imun. Satgas Penanganan COVID-19 menghimbau masyarakat untuk meningkatkan "iman" dengan beribadah sesuai agama dan kepercayaan masing-masing, menjaga "keamanan" diri dengan melakukan memakai masker, mencuci tangan dengan sabun, menjaga jarak dan menghindari kerumunan, dan menjaga kekebalan tubuh dari mengkonsumsi makanan sehat, vitamin dan vaksinasi.

Vaksinasi adalah proses di dalam tubuh, dimana seseorang menjadi kebal atau terlindungi dari suatu penyakit sehingga apabila suatu saat terpajan dengan penyakit tersebut maka tidak akan sakit atau hanya mengalami sakit ringan, biasanya dengan pemberian vaksin (Kementerian Kesehatan, 2021). Vaksinasi sendiri dalam perjalanannya berlangsung tidak sebentar untuk 
mencapai keakuratan dan keamanan untuk diberikan langsung kepada masyarakat umum. Banyak badan farmasi di seluruh dunia berlomba-lomba untuk melakukan penelitian dan menemukan vaksin yang layak untuk membantu mengakhiri pandemi ini. Pemerintah mencanangkan program nasional untuk memberikan vaksin Covid-19 bagi seluruh rakyat Indonesa di ke 34 Provinsi, yang mulai sejak 13 Januari 2021 dan ditargetkan rampung pada Desember 20213. Pemerintah Indonesia juga mulai mencukupi ketersediaan vaksin di seluruh Indonesia dengan memberlakukan 4 tahapan pelaksanaan vaksin covid-19 dimana tahap pertama adalah bagi tenaga kesehatan, tahap kedua adalah petugas pelayanan publik dan lansia $(\geq 60$ tahun), tahap ketiga adalah masyarakat rentan, dan tahap terakhir adalah masyarakat dan pelaku ekonomi sesuai dengan ketersediaan vaksin (Satuan Tugas Penanganan COVID-19., 2021, Kementerian Kesehatan, ITAGI, UNICEF, 2020).

Pada SK Dirjen Nomor HK.02.02/4/1/2021 Tentang Petunjuk Teknis Pelaksanaan Vaksinasi dalam Rangka Penanggulangan Pandemi Covid-19, dijelaskan bahwa vaksinasi COVID-19 bertujuan untuk mengurangi transmisi/penularan COVID-19, menurunkan angka kesakitan dan kematian akibat COVID-19, mencapai kekebalan kelompok di masyarakat (herd immunity) dan melindungi masyarakat dari COVID-19 agar tetap produktif secara sosial dan ekonomi (Kementerian Kesehatan- Direktorat Jenderal Pencegahan dan Pengendalian Penyakit, 2021). Kekebalan kelompok dapat diperoleh ketika cakupan vaksinasi tinggi dan merata di seluruh wilayah. Selain itu dari sisi ekonomi, upaya pencegahan melalui vaksinasi dinilai jauh lebih hemat biaya, bila dibandingkan dengan upaya pengobatan. Namun, pelaksanaan vaksinasi Covid-19 menjadi tantangan tersendiri bagi pemerintah sebab menimbulkan ketidakpercayaan dari sebagian masyarakat. Masyarakat mempertanyakan keamanan, keakuratan, kehalalan, serta banyaknya hoax yang diterima masyarakat yang belum diketahui sumber informasinya.

Menurut data Kementerian Kesehatan (2021), per 24 maret 2021 jumlah kasus covid-19 mencapai 1.476.452 kasus, dengan 1.312.543 sembuh dan 39.983 berakhir dengan kematian, sedangkan capaian pemberian vaksin pada tanggal yang sama, baru tercapai sebanyak $5.978 .251(3,29 \%)$ untuk dosis pertama dan 2.709.545 (1,49\%) yang rampung untuk dosis kedua (Kementerian Kesehatan, 2021). Maka, diperlukan sosialisasi secara massif terhadap seluruh lapisan masyarakat mengenai pentingnya program vaksinasi guna menurunkan anka kematian akibat wabah Covid-19.

Data ITAGI dan UNICEF bersama WHO, mengenai Survei Penerimaan Vaksin COVID-19 di Indonesia diketahui bahwa sekitar dua pertiga responden kemungkinan besar bersedia divaksin dan sisanya yang masih ragu mempertanyakan faktor-faktor terkait vaksin (Kementerian Kesehatan, ITAGI, UNICEF, 2020). Sebesar 6.7\% berasal dari provinsi Banten, Kabupaten Tangerang dimana $7 \%$ responden menyatakan menolak vaksin (Kementerian Kesehatan, ITAGI, UNICEF, 2020). Kabupaten Tangerang dan Provinsi Bali dipilih menjadi sasaran kegiatan PkM, karena memiliki jumlah kasus Covid19 yang masih tinggi dan capaian vaksinasi yang masih rendah. Padahal Pemerintah Kabupaten Tangerang menargetkan capaian vaksin mencapai 15 ribu per hari. Sedangkan Pemerintah Provinsi Bali menargetkan bahwa nantinya kegiatan vaksinasi kepada seluruh masyarakat Bali ditargetkan selesai di tahun 2021. Adanya perjanjian kerjasama antara Fakultas Keperawatan Universitas Pelita Harapan dengan lembaga mitra Dinas 
Kesehatan Kabupaten Tangerang dan Dinas Kesehatan Provinsi Bali turut melatarbelakangi kegiatan PkM ini sebagai bentuk dukungan terhadap pelaksanaan vaksinasi di Kabupaten Tangerang dan Provinsi Bali. Kegiatan Pengabdian kepada Masyarakat dilakukan untuk mendukung upaya pemerintah dalam memerangi COVID-19 di Indonesia dengan memberikan edukasi mengenai manfaat vaksin COVID-19 dan menangkal Hoax terkait vaksinasi.

\section{MASALAH}

Dari analisis situasi didapatkan permasalahan yaitu:

a. Pemerintah mencanangkan program nasional untuk memberikan vaksin Covid-19 bagi seluruh rakyat Indonesa di ke 34 Provinsi, yang mulai sejak 13 Januari 2021 dan ditargetkan rampung pada Desember 2021. Menurut data Kementerian Kesehatan, capaian pemberian vaksin sampai dengan 24 maret 2021, baru tercapai sebanyak 5.978 .251 (3,29\%) untuk dosis pertama dan 2.709.545 (1,49\%) yang rampung untuk dosis kedua.

b. Berdasarkan data Kementerian Kesehatan, ITAGI, UNICEF, dan WHO mengenai Survei Penerimaan Vaksin COVID-19 di Indonesia bahwa sekitar dua pertiga responden kemungkinan besar bersedia divaksin dan sisanya yang masih ragu mempertanyakan faktor-faktor terkait vaksin. Terdapat ketidakpercayaan, kekhawatiran berupa keamanan dan efektifitas dan kehalalan vaksin.

c. Hasil survey yang dilakukan ITAGI dan UNICEF bersama WHO, diketahui bahwa sebanyak 6,7\% berasal dari provinsi Banten, Kabupaten Tangerang dimana 7 \% responden menyatakan menolak vaksin. Kabupaten Tangerang dan Provinsi Bali dipilih menjadi sasaran kegiatan PkM, karena memiliki jumlah kasus Covid-19 yang masih tinggi dan capaian vaksinasi yang masih rendah. Padahal Pemerintah Kabupaten Tangerang menargetkan capaian vaksin mencapai 15 ribu per hari. Sedangkan Pemerintah Provinsi Bali menargetkan bahwa kegiatan vaksinasi kepada seluruh masyarakat Bali ditargetkan selesai di tahun 2021.

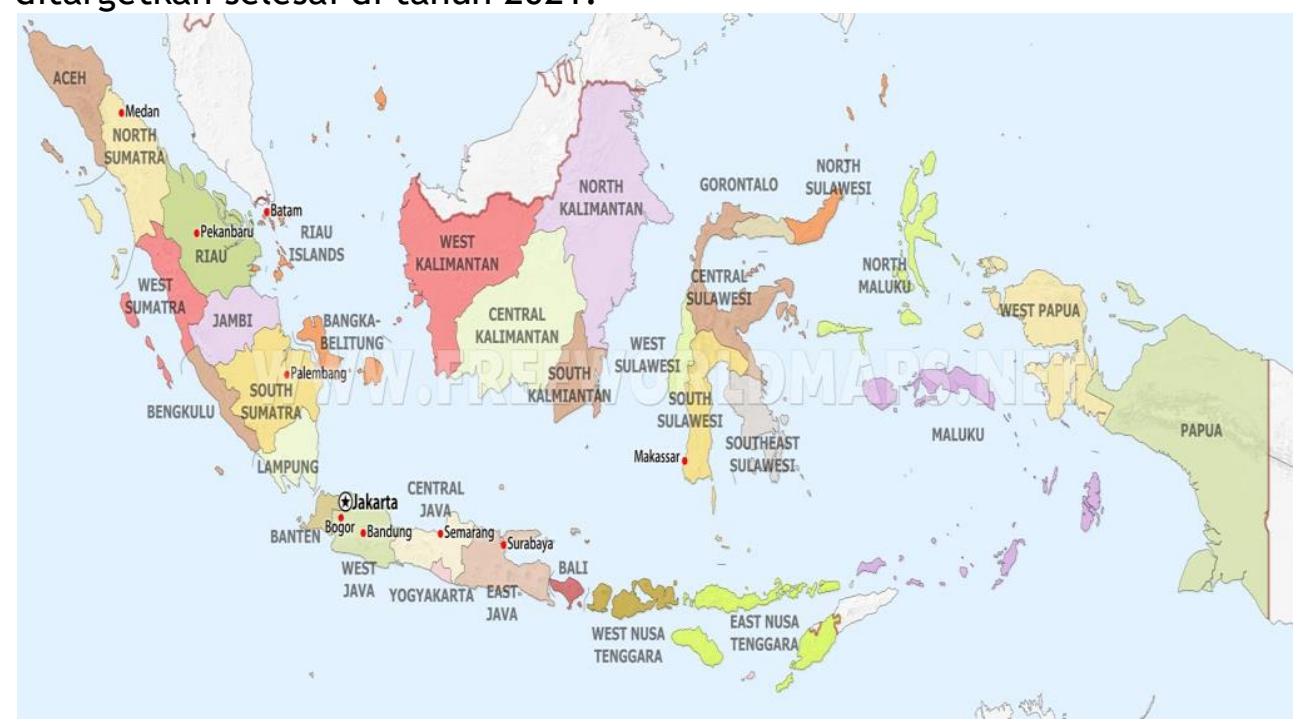

Gambar 1. Peta Lokasi Kegiatan

(Sumber: https://www.freeworldmaps.net/asia/indonesia/) 


\section{METODE}

Solusi yang ditawarkan dalam menyelesaikan permasalahan yang dihadapi adalah dengan mengadakan webinar edukasi pentingnya vaksinasi Covid-19. Tujuan dari webinar ini untuk meningkatkan pemahaman kepada masyarakat tentang manfaaat vaksinasi dan mendukung program nasional dalam vaksinasi Covid-19 di Indonesia sehingga kasus Covid-19 bisa dikendalikan dan capaian vaksinasi Covid-19 optimal mencapai target.

Kegiatan ini dilakukan oleh dosen, edukator klinik, dan mahasiswa dari Fakultas Keperawatan UPH berkerjasama dengan Dinas Kesehatan Kabupaten Tangerang, Dinas Kesehatan Provinsi Bali dan Fakultas Kedokteran UPH. Target awal dari kegiatan PkM ini adalah masyarakat umum yang tinggal di Indonesia khususnya di Kabupaten Tangerang dan Provinsi Bali dengan jumlah peserta sebanyak 200 peserta dengan rentang usia 18-65 tahun. Bentuk kegiatan adalah webinar yang diadakan secara daring. Kegiatan dilaksanakan pada tanggal 4 Juni 2021 pukul 09.00-11.00 WIB. Kegiatan Pengabdian kepada Masyarakat (PkM) dimulai dengan pendaftaran, registrasi dan pre-test, pemaparan materi mengenai manfaat vaksinasi Covid-19 serta dilanjutkan dengan materi kedua mengenai fakta dan mitos dari vaksin COVID-19. Kemudian, diakhiri dengan diskusi, pengisian post-test dan form evaluasi kegiatan.

Adapun manfaat kegiatan ini bagi peserta, yaitu:

a) Memahami manfaat vaksin Covid-19 dan berpartisipasi dalam vaksinasi

b) Tidak mudah terprovokasi dalam menyerap informasi seputar vaksin COVID-19 yang belum jelas kebenarannya.

\section{HASIL DAN PEMBAHASAN}

\subsection{Pelaksanaan Kegiatan}

Kegiatan Pengabdian Kepada Masyarakat (PkM) ini merupakan buah perjanjian kerjasama (PKS) antara Fakultas Keperawatan Universitas Pelita Harapan dengan Dinas Kesehatan Kabupaten Tangerang (Nomor PKS: 043/FoN-UPH/PKS/XII/2019) dan Dinas Kesehatan provinsi Bali (Nomor PKS: 016/FoN-UPH/PKS/III/2020). Topik dipilih untuk turut mendukung program vaksinasi nasional yang sedang digalakkan oleh pemerintah.

Kegiatan PkM dalam bentuk webinar edukasi kesehatan dengan sasaran masyarakat umum, terutama yang berdomisil di wilayah Kabupaten Tangerang dan Provinsi Bali. Koordinasi diantara tim dilakukan dengan 4 kali rapat dimana rapat pertama dimulai pada 26 april 2021. Sedangkan koordinasi tim dengan kedua lembaga mitra dan pembicara dilakukan 6 minggu sebelum pelaksanaan. Poster publikasi kegiatan dan informasi terkait webinar disebarluaskan panitia sejak 3 minggu sebelum pelaksanaan kegiatan. Selain rapat koordinasi dilakukan gladi kotor dan gladi bersih.

Kegiatan PKM dilakukan dalam bentuk Webinar edukasi pentingnya vaksin Covid-19, pada hari Jumat, 4 juni 2021. Webinar dilakukan secara daring menggunakan platform zoom meeting dan Youtube Channel. Webinar dibuka dengan kata sambutan dari Dekan Fakultas Keperawatan Universitas pelita Harapan dan Dinas Kesehatan Provinsi Bali. Edukasi dibagi dalam 2 sesi yaitu:

a. Sesi 1: Mengenal Vaksin Covid-19 dan Manfaatnya, dr. Thomas Robertus, Sp.MK (Rs. Siloam Kebun Jeruk)

b. Sesi 2: Fakta dan Mitos (Hoax) terkait vaksin COVID-19, dibawakan oleh dr Hendra Tarmizi, MARS (Dinas Kesehatan Kabupaten Tangerang) 

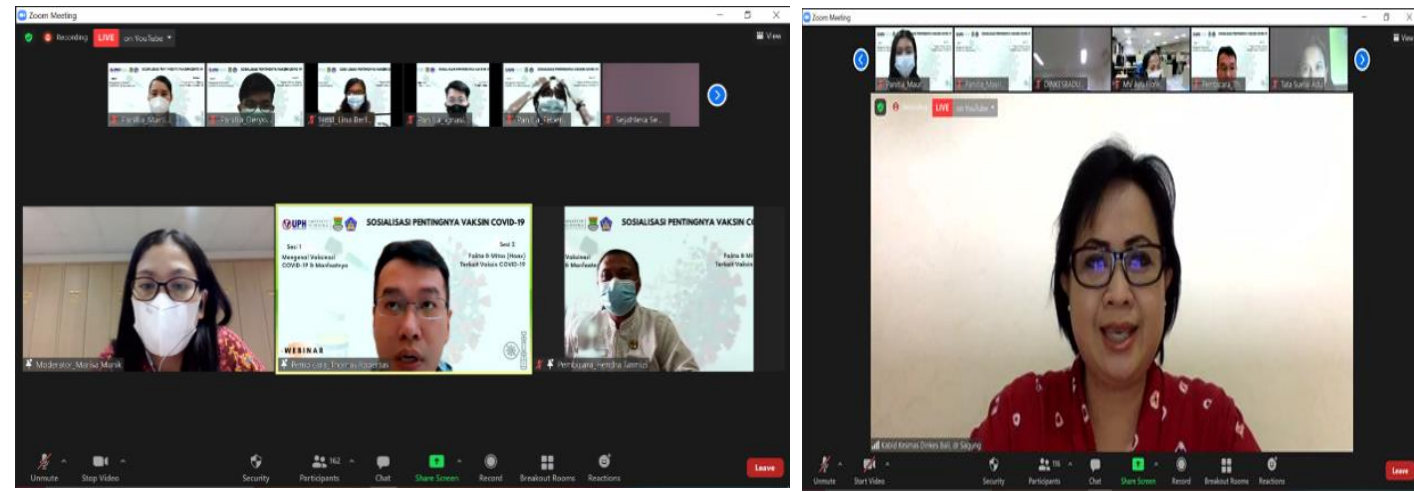

Gambar 2 dan 3: Dokumentasi Kegiatan webinar

\subsection{Hasil Kegiatan}

Dari 227 peserta yang mengisi link registrasi, pre-test, post-test dan evaluasi. Hasil kegiatan disajikan pada tabel 1-3 dan pada gambar 4-7.

4.2.1 Karakteristik Peserta

Tabel 1. Gambaran Karakteristik Demografi Peserta Webinar $(n=227)$

\begin{tabular}{llll}
\hline Karakteristik & \multicolumn{1}{c}{ Kategori } & (n) & (\%) \\
\hline Provinsi & Banten & 50 & 22 \\
& Bali & 9 & 4 \\
& DKI Jakarta & 15 & 6,6 \\
& Jawa Barat & 21 & 9,25 \\
& Jawa Timur & 46 & 20,26 \\
& Jawa Tengah & 14 & 6,2 \\
& NTT & 25 & 11 \\
& Sumatera (Sumut, Aceh, Jambi, lampung, & 28 & 12,3 \\
& Sumsel) & & \\
& Kalimantan, Sulawesi, Maluku & 20 & 8,8 \\
\hline Usia & 12-16 tahun & 1 & 0,4 \\
& 17-25 tahun & 151 & 66,5 \\
& 26-35 tahun & 38 & 16,7 \\
& 36-45 tahun & 19 & 8,4 \\
& 46-55 tahun & 13 & 5,7 \\
& 56-65 tahun & 5 & 2,2 \\
& >65 tahun & 0 & 0 \\
\hline Pendidikan & SD & 1 & 0,4 \\
& SMP & 0 & 0 \\
& SMA & 46 & 20,3 \\
& S1 & 153 & 67,4 \\
& S2 & 23 & 10,1 \\
& S3 & 4 & 1,8 \\
\hline Pekerjaan & Petugas Kesehatan & 27 & 11,9 \\
& Dosen/Guru & 33 & 14,5 \\
& Pegawai Negri Sipil & 11 & 4,8 \\
& Karyawan swasta & 7 & 3,1 \\
& Aparat Hukum (Polisi, TNI, Satpol PP, & 0 & 0 \\
& Satpam) & & \\
& Pedagang/Petani/Peternak & 1 & 0,4 \\
& Ibu Rumah Tangga & 3 & 1,3 \\
& Pelajar/Mahasiswa & 142 & 62,6 \\
& Lainnya & 3 & 1,3 \\
\hline & & &
\end{tabular}


Pada tabel 1 diketahui karakteristik Peserta yaitu: berasal dari berbagai Provinsi (mayoritas dari Banten yaitu sebanyak 22\%), berbagai usia (mayoritas adalah 17-25 tahun yaitu sebanyak 66,5\%), beragam jenjang pendidikan (mayoritas adalah S1 yaitu sebanyak 67,4\%) dan beragam profesi (mayoritas adalah mahasiswa sebanyak 62,6\%).

\subsubsection{Pengetahuan Peserta}

Tabel 2. Distribusi Nilai Pre-Test dan Post-Test Peserta Webinar $(\mathrm{n}=227)$

\begin{tabular}{lll}
\hline $\begin{array}{l}\text { Komponen } \\
\text { Nilai }\end{array}$ & Pre-Test & Post-Test \\
\hline Range & $3-10$ & $3-10$ \\
\hline Mean (rerata) & 7,28 & 8,29 \\
\hline Median & 7 & 9 \\
\hline
\end{tabular}

Pada tabel 2 diketahui bahwa untuk nilai pre-test range nilai 3-10, Mean 7,28 dan Median 7. Sedangkan untuk nilai post-test diketahui range nilai 3-10, mean 8,29 dan median 9. Maka dapat disimpulkan bahwa terjadi peningkatan pengetahuan peserta webinar setelah sesi edukasi dan sesi tanya jawab.

Penelitian yang dilakukan Lee et al., (2021) menemukan bahwa pengetahuan secara langsung memengaruhi sikap (misalnya, persepsi risiko dan keyakinan efikasi) dan ketiga perilaku pencegahan (mengenakan masker wajah, mempraktikkan kebersihan tangan, dan menghindari tempat ramai). Tingkat pengetahuan bervariasi dipengaruhi oleh karakteristik sosiodemografi. Penelitian yang dilakukan Lee et al., (2021) dan Khaled et al., (2020) menunjukkan bahwa tingkat pendidikan yang lebih tinggi dan gender perempuan memiliki tingkat pengetahuan yang lebih tinggi. Penelitian yang dilakukan Sulistyawati et al., (2021) menemukan bahwa usia dan pendidikan secara signifikan berhubungan dengan pengetahuan.

Tabel 3. Distribusi Jawaban Benar Peserta Webinar pada Pertanyaan Pretest dan Post-Test $(\mathrm{n}=227)$

\begin{tabular}{|c|c|c|c|c|c|}
\hline \multirow[t]{2}{*}{ No } & \multirow[t]{2}{*}{ Pertanyaan } & \multicolumn{2}{|c|}{ Pre-test } & \multicolumn{2}{|c|}{ Post Test } \\
\hline & & $n$ & $\%$ & $n$ & $\%$ \\
\hline 1. & $\begin{array}{l}\text { Penularan COVID-19 adalah } \\
\text { melalui? } \\
\text { Jawaban: Droplet }\end{array}$ & 183 & 80,6 & 215 & 94,7 \\
\hline 2. & $\begin{array}{l}\text { Manakah dari hal-berikut } \\
\text { yang TIDAK termasuk bentuk } \\
\text { pencegahan dari COVID-19? } \\
\text { Jawaban: Mengkonsumsi fast } \\
\text { food }\end{array}$ & 226 & 99,6 & 226 & 99,6 \\
\hline 3. & $\begin{array}{l}\text { Tujuan dari vaksinasi COVID- } \\
19 \text { adalah? } \\
\text { Jawaban: Menurunkan angka } \\
\text { kesakitan, kematian, dan } \\
\text { kecacatan }\end{array}$ & 39 & 17,2 & 112 & 49,3 \\
\hline 4. & $\begin{array}{l}\text { KIPI (Kejadian Ikutan Pasca } \\
\text { Imunisasi) adalah? } \\
\text { Jawaban: Kejadian yang } \\
\text { tidak diharapkan yang dilihat } \\
\text { tanpa menilai apakah ada }\end{array}$ & 55 & $\begin{array}{c}24, \\
2\end{array}$ & 111 & 48,9 \\
\hline
\end{tabular}




\begin{tabular}{|c|c|c|c|c|c|}
\hline & $\begin{array}{ll}\text { hubungan } & \text { sebab-akibat } \\
\text { dengan vaksin } & \\
\end{array}$ & & & & \\
\hline 5. & $\begin{array}{l}\text { Berikut adalah efek samping } \\
\text { dari pemberian vaksin COVID- } \\
19 \text { yaitu? } \\
\text { Jawaban: Demam dan nyeri } \\
\text { otot }\end{array}$ & 220 & $\begin{array}{l}96, \\
9\end{array}$ & 221 & 97,4 \\
\hline 6. & $\begin{array}{l}\text { Siapa sajakah yang dapat } \\
\text { menerima vaksin COVID-19? } \\
\text { Jawaban: Semua benar }\end{array}$ & 220 & $\begin{array}{l}96, \\
9\end{array}$ & 220 & 96,9 \\
\hline 7. & $\begin{array}{l}\text { Imunitas terhadap COVID-19 } \\
\text { dari seseorang yang tidak } \\
\text { divaksin sama saja dengan } \\
\text { seseorang yang telah } \\
\text { menerima vaksin COVID-19? } \\
\text { Jawaban: Salah }\end{array}$ & 197 & $\begin{array}{l}86, \\
9\end{array}$ & 209 & 92,1 \\
\hline 8. & $\begin{array}{l}\text { Efek samping pemberian } \\
\text { vaksin COVID-19 lebih besar } \\
\text { dari pada efek manfaat yang } \\
\text { didapatkan? } \\
\text { Jawaban: Salah }\end{array}$ & 192 & $\begin{array}{l}84, \\
6\end{array}$ & 193 & 85 \\
\hline 9. & $\begin{array}{l}\text { Seseorang yang telah } \\
\text { mendapatkan vaksin COVID- } \\
19 \text { dengan dosis penuh (2 } \\
\text { kali), maka tidak perlu lagi } \\
\text { untuk melakukan protokol } \\
\text { kesehatan (Menggunakan } \\
\text { masker, mencuci tangan, } \\
\text { menjaga jarak dan menjauhi } \\
\text { kerumunan) } \\
\text { Jawaban: Salah }\end{array}$ & 207 & $\begin{array}{l}91, \\
2\end{array}$ & 212 & 93,4 \\
\hline 10. & $\begin{array}{l}\text { Obat-obatan herbal seperti } \\
\text { minyak kayu putih, minyak } \\
\text { kelapa murni (VCO) dan } \\
\text { campuran air kelapa muda, } \\
\text { jeruk nipis dan garam dapat } \\
\text { digunakan untuk mencegah } \\
\text { dan menyembuhkan COVID- } \\
\text { 19? } \\
\text { Jawaban: Salah }\end{array}$ & 113 & $\begin{array}{l}49 \\
8\end{array}$ & 177 & 78 \\
\hline
\end{tabular}

Pada tabel 3, diketahui dari 10 pertanyaan pre-test ke post-test, terdapat 9 pertanyaan kecuali nomor 6 yang jumlah dan persentase jawaban benar yang diberikan peserta meningkat dari pre-test ke post-test. Peningkatan signifikan $(>25 \%)$ jawaban benar peserta dari pre-test ke post-test terdapat pada pertanyaan butir 3, 4 dan 10 . Ketiga pertanyaan tersebut terkait tujuan pemberian vaksin COVID-19, KIPI (Kejadian Ikutan Pasca Imunisasi) dan Hoax seputar obat-obatan herbal dalam penyembuhan COVID-19. Maka dapat disimpulkan bahwa pengetahuan atau pemahaman masyarakat terkait vaksinasi dan Hoax seputar vaksin masih kurang. 


\subsubsection{Sikap dan Kondisi Peserta Terhadap Vaksin-COVID-19}

Apakah sebelumnya Anda pernah terinfeksi COVID-19?

227 jawaban

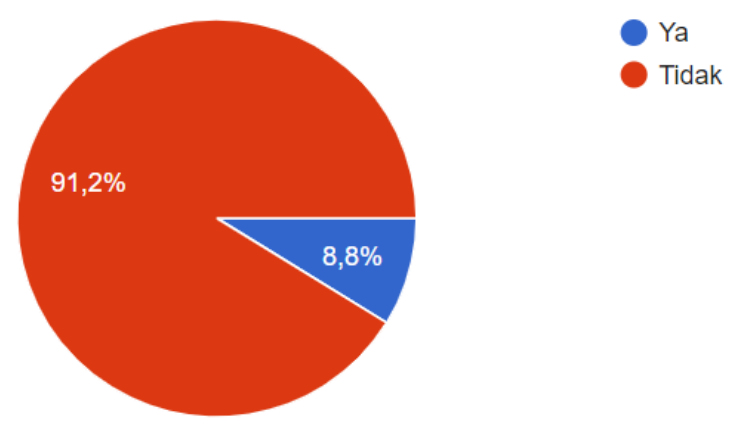

Gambar 4. Riwayat Terinfeksi COVID-19

Pada gambar 4, diketahui bahwa sebanyak 207 (91,2\%) peserta belum pernah terinfeksi COVID-19 dan sebanyak $20(8,8 \%)$ peserta sudah pernah terinfeksi COVID-19.

Menurut anda apakah vaksin COVID-19 penting untuk diberikan?

227 jawaban

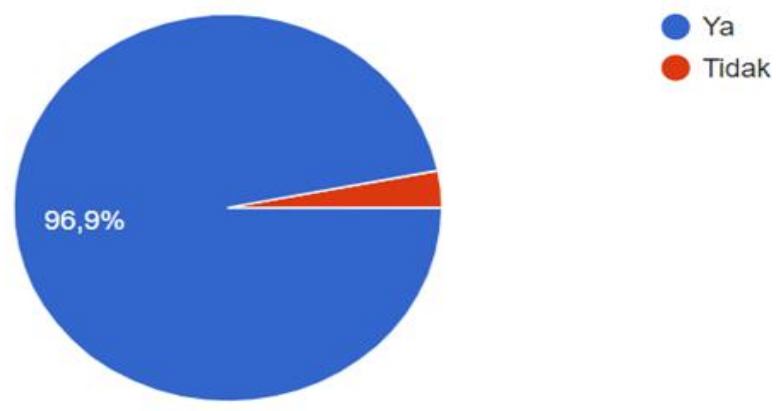

Gambar 5. Sikap Peserta Menilai Pentingnya Vaksin COVID-19

Pada gambar 5, diketahui bahwa sebanyak 220 (96,9\%) peserta memiliki sikap positif yaitu menilai penting pemberian vaksin COVID-19 dan sebanyak $7(3,1 \%)$ peserta memiliki sikap negatif yaitu menilai tidak penting pemberian vaksin COVID-19.

Sikap positif terhadap vaksinasi memengaruhi perilaku seseorang untuk turut divaksin. Penelitian yang dilakukan Lee et al., (2021) menemukan bahwa di antara faktor-faktor yang memengaruhi perilaku pencegahan COVID-19, keyakinan efikasi adalah faktor praktik yang paling berpengaruh dan signifikan. Penelitian lainnya yang dilakukan Sulistyawati et al., (2021) menemukan bahwa beberapa sikap dipengaruhi oleh usia dan pekerjaan. Penelitian Khaled et al., (2020) menemukan bahwa perempuan memiliki sikap positif lebih besar terhadap perilaku pencegahan Covid-19 dibandingkan laki-laki 
Dari mana sumber informasi terkait vaksin covid-19 sering anda dapatkan?

227 jawaban

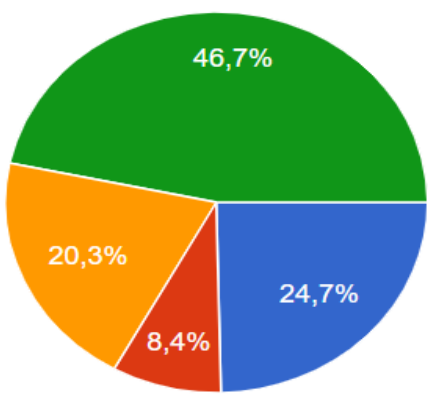

Petugas kesehatan

Televisi/Radio

Internet

Media sosial

Gambar 6. Sumber Informasi yang Diterima Peserta Terkait Vaksin Covid-19

Pada gambar 6, diketahui bahwa sumber informasi terkait vaksin COVID19 berasal dari media sosial yaitu sebanyak 106 (46,7\%) peserta, dari petugas kesehatan yaitu sebanyak $56(24,7 \%)$ peserta, berasal dari internet yaitu sebanyak $46(20,3 \%)$ peserta dan berasal dari televisi/radio yaitu sebanyak $19(8,4 \%)$.

Paparan informasi turut memengaruhi pengetahuan dan sikap seseorang atau masyarakat untuk melakukan upaya pencegahan Covid-19. Sama dengan hasil PKM, penelitian yang dilakukan Sulistyawati et al., (2021) menemukan bahwa Informasi tentang cara pencegahan COVID-19 menjadi informasi yang paling dicari di masa pandemi ini. Media sosial menjadi sumber informasi favorit, dengan jenis visualisasi yang paling populer adalah tabel yang berisi angka-angka (Sulistyawati et al., 2021).

Apakah Anda sudah mendapat vaksin COVID-19 saat ini?

227 jawaban

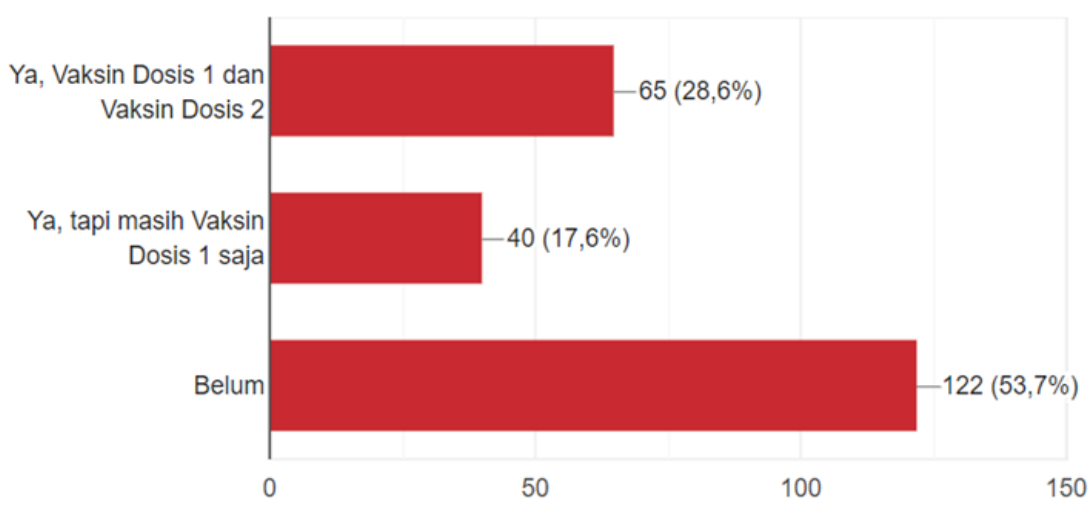

Gambar 7. Gambaran Capaian Pemberian Vaksin Pada Peserta

Pada gambar 7, diketahui bahwa capaian pemberian vaksin pada peserta diketahui sebanyak $122(53,7 \%)$ peserta belum pernah mendapatkan vaksin COVID-19, sebanyak $65(28,6 \%)$ peserta sudah menerima vaksin COVID-19 dengan dosis lengkap (dosis pertama dan kedua), dan sebanyak 40 (17,6\%) peserta baru mendapatkan vaksin COVID-19 dosis pertama. 
Faktor-faktor yang turut memengaruhi perilaku seseorang dalam pencegahan COVID-19 termasuk vaksinasi antaralain; pengetahuan, sikap dan keterpaparan informasi terkait vaksinasi. Penelitian yang dilakukan Lee et al., (2021) menemukan bahwa terdapat hubungan antara pengetahuan dengan 3 perilaku pencegahan (penggunaan masker, mencuci tangan dan menghindari tempat kerumunan. Penelitian tersebut juga menemukan bahwa level pengetahuan dipengaruhi oleh karakteristik sosial demografi, diantaranya adalah tingkat pendidikan, dimana pada tingkat Pendidikan tinggi menunjukkan tingkat pengetahuan yang tinggi (Lee et al., 2021). Penelitian lainnya yang dilakukan Sulistyawati et al., (2021) menemukan bahwa secara umum, pengetahuan masyarakat tentang COVID-19 sudah cukup dan sebagian besar masyarakat memiliki sikap positif terhadap COVID19, namun beberapa perilaku pencegahan sesuai protocol kesehatan masih rendah dan memberikan respon negatif terhadap kebijakan pemerintah termasuk vaksinasi. Kepemilikan asuransi kesehatan dan gender secara signifikan berhubungan dengan tindakan pencegahan (Sulistyawati et al., 2021).

Upaya pencegahan dan penananganan Covid-19 masih terus dilakukan hingga saat ini. Ketahanan (resiliensi) adalah kunci untuk memungkinkan pendekatan dan tanggapan terkoordinasi yang cepat, sukses, berkelanjutan terhadap COVID-19 dan krisis dan keadaan darurat di masa depan, yaitu ketahanan bangsa, masyarakat, meskipun tidak hanya kesehatan fisik dan mental, tetapi juga dalam infrastruktur ekonomi, fisik dan sosialnya serta alam dan lingkungan (Djalante et al., 2020)

\section{KESIMPULAN}

a. Webinar diikuti oleh 227 peserta yang berasal dari berbagai provinsi (mayoritas dari Banten yaitu sebanyak 22\%), berbagai usia (mayoritas adalah 17-25 tahun yaitu sebanyak $66,5 \%$ ), beragam jenjang pendidikan (mayoritas adalah S1 yaitu sebanyak $67,4 \%$ ) dan beragam profesi (mayoritas adalah mahasiswa sebanyak 62,6\%).

b. Gambaran pengetahuan peserta terkait vaksinasi COVID-19 diketahui sudah baik. Hal ini terlihat dari pre-test rerata nilai sebesar 7.28 dan Nilai Median 7. Bila dibandingkan dengan nilai post-test dengan rerata nilai 8.29 dan Nilai Median 9, maka disimpulkan terjadi peningkatan pengetahuan peserta setelah diberikan edukasi.

c. Gambaran sikap dan kondisi peserta diketahui sebanyak $207(91,2 \%)$ peserta belum pernah terinfeksi COVID-19, sebanyak 220 (96,9\%) peserta memiliki sikap positif yaitu menilai penting pemberian vaksin COVID-19, sebanyak $106(46,7 \%)$ peserta mendapatkan informasi terkait vaksin COVID-19 berasal dari media sosial, dan terkait pemberian vaksin diketahui mayoritas peserta yaitu sebanyak 122 (53,7\%) peserta belum pernah mendapatkan vaksin COVID-19.

d. Edukasi kesehatan kepada masyarakat sangat penting dilakukan, mengingat belum semua masyarakat memiliki pemahaman yang baik terkait vaksinasi COVID-19, kegiatan pengabdian masyarakat yang dilakukan oleh Dosen adalah pelaksanaan Tri Dharma Perguruan Tinggi dalam upaya mensukseskan program dan kebijakan Pemerintah terkait vaksinasi Covid-19.

e. Upaya pencegahan dan pengendalian COVID-19 masih perlu terus dilakukan oleh semua pihak. 


\section{UCAPAN TERIMAKASIH}

Penulis berterimakasih kepada Fakultas Keperawatan Universitas Pelita Harapan yang telah mendanai pelaksanaan kegiatan PkM Mandiri ini dengan Nomor PkM: PM-019-M/FoN/IV/2021 dan kepada Lembaga Penelitian dan Pengabdian Masyarakat (LPPM) Universitas Pelita Harapan yang telah mendukung Publikasi hasil PKM ini. Demikian juga kepada Dinas Kesehatan Kabupaten Tangerang dan Dinas Kesehatan Provinsi Bali yang menjadi mitra dalam pelaksanaan kegiatan PkM.

\section{DAFTAR PUSTAKA}

Djalante, R., Lassa, J., Setiamarga, D., Sudjatma, A., Indrawan, M., Haryanto, B., Mahfud, C., Sinapoy, M. S., Djalante, S., Rafliana, I., Gunawan, L. A., Surtiari, G. A. K., \& Warsilah, H. (2020). Review and analysis of current responses to COVID-19 in Indonesia: Period of January to March 2020. Progress in Disaster 6. https: / /doi.org/10.1016/J.PDISAS.2020.100091

Kementerian Kesehatan- Direktorat Jenderal Pencegahan dan Pengendalian Penyakit. (2021). SK Dirjen Nomor HK.02.02/4/1/2021 Tentang Petunjuk Teknis Pelaksanaan Vaksinasi dalam Rangka Penanggulangan Pandemi Covid-19.

https://covid19.go.id/storage/app/media/Regulasi/2021/Januari/Final SK Dirjen Juknis Vaksinasi COVID-19 02022021.pdf

Kementerian Kesehatan, ITAGI, UNICEF, dan W. (2020). Survei Penerimaan Vaksin COVID-19 di Indonesia. https://covid19.go.id/storage/app/media/Hasil Kajian/2020/November/vaccine-acceptance-survey-id-12-11-2020final.pdf

Kementerian Kesehatan. (2021). Seputar Pelaksanaan Vaksinasi COVID-19. FAQ. https://kesmas.kemkes.go.id/assets/uploads/contents/others/FAQ_VAKSI NASI_COVID_call_center.pdf

Kementerian Kesehatan. (2021). Data Vaksinasi Covid-19, update 24 maret 2021. Khaled, A., Siddiqua, A., \& Makki, S. (2020). The Knowledge and Attitude of the Community from the Aseer Region, Saudi Arabia, Toward COVID-19 and Their Precautionary Measures Against the Disease. Risk Management and Healthcare Policy, 13, 1825. https://doi.org/10.2147/RMHP.S271899

Lee, M., Kang, B.-A., \& You, M. (2021). Knowledge, attitudes, and practices (KAP) toward COVID-19: a cross-sectional study in South Korea. BMC Public Health 2021 21:1, 21(1), 1-10. https://doi.org/10.1186/S12889-021-10285$Y$

Satuan Tugas Penanganan COVID-19. (2021). Survei Penerimaan Vaksin COVID 19 di Indonesia. https://covid19.go.id/storage/app/media/Hasil Kajian/2020/November/vaccine-acceptance-survey-id-12-11-2020final.pdf

Satuan Tugas Penanganan COVID-19. (2020). Perubahan Perilaku Penanganan COVID-19.

Sulistyawati, S., Rokhmayanti, R., Aji, B., Wijayanti, S. P. M., Hastuti, S. K. W., Sukesi, T. W., \& Mulasari, S. A. (2021). <p>Knowledge, Attitudes, Practices and Information Needs During the COVID-19 Pandemic in Indonesia</p>. Risk Management and Healthcare Policy, 14, 163-175. https://doi.org/10.2147/RMHP.S288579

World Health Organization. (2021). WHO Coronavirus Disease (COVID-19) Dashboard. https://covid19. who.int/table 